\title{
Targeting sustainable bioeconomy: A new development strategy for Southern European countries. The Manifesto of the European Mezzogiorno
} \author{
Sofia Mannelli President ${ }^{\mathrm{g}}$, Juan Carlos Parajó Professor ${ }^{\mathrm{h}}$, \\ Polycarpos Polycarpou Chief Agricultural Research Officer ${ }^{\mathrm{i}}$, \\ Anastasia Zabaniotou Professor ${ }^{j}$ \\ a Organic Technologies Laboratory, National Technical University of Athens, Greece \\ b STAR AgroEnergy REG-POT Project, University of Foggia, Italy \\ ${ }^{c}$ Instituto de Biologia Experimental e Tecnologica (IBET), Oeiras, Portugal \\ d Cyprus Energy Agency, Lefkosia, Cyprus \\ e Bioenergy Unit, National Laboratory of Energy and Geology, Lisbon, Portugal \\ ${ }^{\mathrm{f}}$ Energy and Environmental Technologies Area, CIRCE, Zaragoza, Spain \\ ${ }^{g}$ Association "Chimica Verde Bionet", Arezzo, Italy \\ ${ }^{\mathrm{h}}$ Department of Chemical Engineering, University of Vigo, Spain \\ ${ }^{\mathrm{i}}$ Agricultural Research Institute, Lefkosia, Cyprus \\ ${ }^{\mathrm{j}}$ Department of Chemical Engineering, Aristotle University of Thessaloniki, Greece
}

Emmanuel Koukios Director ${ }^{\mathrm{a},}{ }^{*}$, Massimo Monteleone Coordinator ${ }^{\mathrm{b}}$, Manuel Jose Texeira Carrondo Vice President ${ }^{c}$, Anthi Charalambous Director ${ }^{\mathrm{d}}$, Francisco Girio Head ${ }^{\mathrm{e}}$, Eva López Hernández Project Manager ${ }^{\mathrm{f}}$,

\section{A R T I C L E I N F O}

\section{Article history:}

Received 13 August 2016

Received in revised form 5 April 2017

Accepted 5 May 2017

Available online 5 May 2017

\section{Keywords:}

Bio-economy

Biobased development

Sustainability

Southern Europe

\begin{abstract}
A B S T R A C T
This policy-oriented opinion paper, which has taken the form of a Manifesto, is co-authored by scientists and engineers from Southern European Union countries that are presently experiencing deep and complex systemic crises: Portugal, Spain, Italy, Greece and Cyprus. With their Manifesto, the authors advocate the adoption of a new development model, focusing on the target of sustainable bioeconomy, around which other development themes and topics will crystallize. Implementing this model will act as a locomotive to get the economies and societies of these countries efficiently out of their crises, and smoothly into greener post-crisis pastures. The proposal is articulated in ten critical steps or theses for immediate action by the policy- and decision-makers, as well as industry, markets and other key actors within this troubled area of the European Mezzogiorno. Corroborating evidence of these theses comes in the form of short reports or "letters" on the key topics of this Manifesto from the countries and regions concerned.
\end{abstract}

๑) 2017 Elsevier Ltd. All rights reserved.

\section{* Corresponding author.}

E-mail addresses: koukios@chemeng.ntua.gr (E. Koukios), star.7fp@gmail.com (M. Monteleone),mjtc@itab.unl.pt (M.J. Texeira Carrondo),director.cea@cytanet. com.cy (A. Charalambous), francisco.girio@lneg.pt (F. Girio), evalohe@fcirce.es (E.L. Hernández), sofia.mannelli@email.it (S. Mannelli), jcparajo@uvigo.es (J.C. Parajó), p.polycarpou@arinet.ari.gov.cy (P. Polycarpou), azampani@gmail.com (A. Zabaniotou).

\section{Introduction: a call to action}

\subsection{A time of change}

The time of crisis is a time for bold decisions. It is specifically a time for decisions affecting change, especially strategic change; this is the type of change needed to urgently get us out of the crisis and safely lead us to post-crisis greener pastures (Ferguson, 2013). In the present text we intend to advocate such a strategic shift in the development strategy followed by our countries, all of them 